\title{
Quantification of Exopolysaccharide Produced by Bacillus subtilis and the Effect of Different Factors on its Production
}

\author{
Raghad R. Al-Abbasi \\ Department of Biophysics/ College of Science/ University of Mosul
}

(Received 26/12/2013 ; Accepted 10/3/2014)

\begin{abstract}
The present study included the extraction and characterization of EPS production by a local soil isolate Bacillus subtilis and examine the effect of different factors $\mathrm{pH}$, inoculums size, incubation periods, and carbon, nitrogen and phosphate sources on EPS production. The exopolysaccharide was recovered from the culture supernatant by using a cold ethanol precipitation. The total carbohydrate content was determined by phenol sulfuric acid method at $488 \mathrm{~nm}$, and major structural groups were detected by Fourier transform infrared (FTIR) spectroscopy at frequency range of 400 to $4000 \mathrm{~cm}^{-1}$. Basal salt solution (BSS) showed higher efficacy in supporting the bacteria to produce EPS $(0.986 \mathrm{mg} / \mathrm{ml})$ as dry weight. The study showed that glucose and fructose were gave maximum EPS production as a carbon source along with ammonium chloride as a nitrogen source. The optimal medium conditions were $\mathrm{pH} 7.0$, inoculum size 5-6\%, after four days of incubation to promote the maximum EPS production for the bacteria under study.
\end{abstract}

Keywords: Bacillus subtilis, Exopolysaccharide, FTIR spectroscopy.

\section{Bacillus subtilis القير الكي المتعد السكربك الخارجي المنتج بولمطة و تأثير عوللم مختلفة في إنتاجه}

\section{الملخص}

تضضمنت الدرلسة لستخلاص وتوصف إنتاج متعدد للسكريت الخارجي لبكتريا Bacillus subtilis المعزولة من التربة ودرلسة تأثير عولمل مختلفة الاس الهيدروجيني وحجم اللقاح وفترة التحضين ومصادر مختلفة من الكربون والنتروجين والفنفور في إنتلجه . م ترسيب متعدد للسكريت الخارجي بلستخدلم الايثانول المبرد وقدرمحتوى الكاربوهيدرات الكلي بطريقة الفينول حلمض الكبريتيك عند الطول الموجي488 نانوميتر، وم تحديد المجلمبع التركيبية بلستخدلم طف الأثعة تهت الحمراء عند

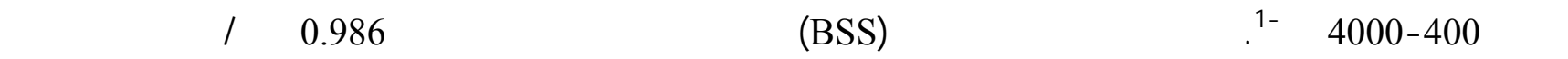

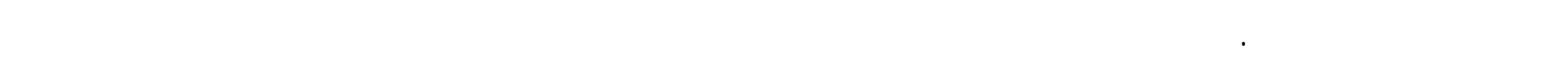

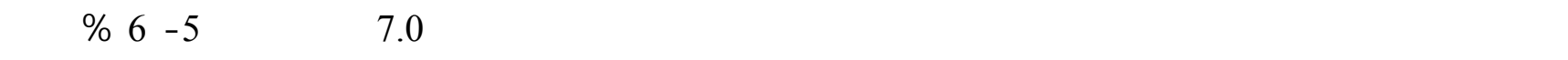
فترة تحضين أربعة أيلم لدعم إنتلجية أعلى لمتعدد للسكريلت الخارجي للبكتريا قيد الدرلسة.

INTRODUCTION

Microbial cells can persist in a free- living life style, while the majority of them establish a very complex and highly organized communities. For example, Bacillus subtilis forms high structured colonies on semi-solid surfaces and in non- agitated liquid culture usually forms a floating biofilm called a pellicle at the air-liquid interface as a consequence of extracellular matrix production. The main component of this matrix $90 \%$ or more is an exopolysaccharide (EPS) which aid binding the cells together in the biofilm (Nadell et al., 2009; Lemon et al., 2008; Türetgen et al., 
2012). EPS is a high molecular weight polymer consisting of monosaccharides and some non carbohydrate subunits such as protein; it may exists as tight capsules or loosely slimes or secreted to the surrounding environment (Rubinstein et al., 2012; Bragadeeswaran et al., 2011). The chemical composition of the EPS depends on the genetics of microbial cells and the physiochemical environment in which the biofilm matrix develops (Marvasi et al., 2010).

Substances within the EPS have multiple functions; some are energy and nutrient reservoir, play an important role in surface adhesion and interaction between bacteria and their environments, and may have many potential applications in a broad range of fields, for instance textiles, pharmaceuticals, oil recovery and metal removal in mining and industrial waste treatment (Marvasi et al., 2010; Orsod et al., 2012; Bragadeeswaran et al., 2011). They also have a vital role in biofilm formation, maintaining primary cellular functions and protection of bacterial cell from desiccation, predators and antibacterial elements (Penge et al., 2008).

In soil, the produced biofilm by $B$. subtilis on the plant root protects the plants from variety of pathogens (Kolodkin-Gal et al., 2012); members of the genus Bacillus are among the first successful biocontrol agents used against the insects and other pathogens as it can produce a variety of lipoproteins and other extracellular polymers which are potent biosurfuctant (Bais et al., 2004). They also play a role in degradation of organic polymers as they can form flocculation as a result of EPS synthesis which can be also a quick method for waste water treatment as their intermediates are harmless and biodegradable with no toxicity or secondary pollution (Bais et al., 2004; Wang et al., 2011). The current study focuses on EPS produced by B. subtilis because it is ubiquitous, present in almost all ecosystems and the EPS produced by it has significant ecological relevance (Earl et al., 2008). This study searches the production and extraction of the exopolysaccharide of the local soil isolate $B$. subtilis and determined the optimal culture condition that enhance maximum EPS production.

\section{Bacterial isolate and culture medium}

\section{MATERIALS AND METHODS}

The local soil isolate of B. subtilis was diagnosed in Bacterial Strains Bank Unit / Biology dept. / college of Science in Mosul University. Bacto ${ }^{\circledR}$ Nutrient broth was used for subculturing the bacterium at $37^{\circ} \mathrm{C}$.

\section{Medium and conditions for primary EPS production}

The basal salt solution (BSS) supplemented with 3\% glucose was used as a basal medium for production with the initial $\mathrm{pH}$ value at $7.1 \pm 0.1$. The medium was inoculated with $2 \mathrm{ml}$ of $18 \mathrm{~h}$ culture of $B$. subtilis at $37^{\circ} \mathrm{C}$ for 3 days as a primary condition for EPS production (Bragadeeswaran et al., 2011). Other basal medium was tested for the efficacy of EPS production, nitrogen- free medium (NFM) and chemically defined medium (CDM), (Borgio et al., 2009).

\section{Isolation and extraction of EPS}

Bacterial cells grown in the basal medium were precipitated by centrifugation $(5000 \mathrm{rpm}$ for 10min.); cooled ethanol alcohol was gently added to the supernatant in 1:2(v/v) and incubated at $4^{\circ} \mathrm{C}$ for $24 \mathrm{hr}$ to precipitate the EPS from the supernatant. The sediment EPS was collected by centrifuge at $6000 \mathrm{rpm}$ at room temperature for $20 \mathrm{~min}$; then dried completely at $70^{\circ} \mathrm{C}$ for $24-48 \mathrm{hr}$ and the powdered EPS was collected in an eppendroff tube and weighed (Ohno et al., 2000).

\section{Quantitative analysis of EPS}

The quantificational estimates were done to assess the obtained EPS involved the weight of precipitated EPS in term of wet weight, and the weight of dried EPS as dry weight. The concentration of the carbohydrates by phenol-sulfuric acid method (Dubois et al.,1956) and proteins by Lowry's method (Lowry et al.,1951) was appointed by reading the optical density spectrophotometrically. 


\section{Qualitative analysis of EPS}

The crude EPS was analyzed by the Fourier Transform Infrared (FTIR)-600 spectroscope (Biotech engineering management CO.LTD. (U.K.)) to screen for the presence of C-H, C=O and O$\mathrm{H}$ groups in the sample by mixing one part of the crude EPS with nine parts of dried potassium bromide $(\mathrm{KBr})$ and then compress them to prepare a thin salt disc. The discs were subjected to FTIR- spectra measurement in the frequency range of 400 to $4000 \mathrm{~cm}^{-1}$ (Vidhyalakshmi and Nachiyar, 2011).

\section{Assessment of the effect of culture medium- associated factors on the yield EPS}

Several selected factors were tested to study their effect on the amount of yield EPS using basal salt solution BSS as a basal medium. To find out the optimal carbon and nitrogen source, BSS medium supplemented with 3\% glucose, $0.1 \%, 0.05 \%$ inorganic and organic nitrogen source respectively, was provided separately with different selected sources instead of the source employed in basal medium, as listed in Table (1). To find out the suitable concentration of Phosphate salts for EPS yield, different concentrations were separately provided instead of $0.07 \% \mathrm{~K}_{2} \mathrm{HPO}_{4}$ and $0.03 \%$ $\mathrm{KH}_{2} \mathrm{PO}_{4}$ employed in BSS medium. The amount of EPS by each factor was measured as carbohydrate concentration in $\mu \mathrm{g} / \mathrm{ml}$.

Table 1: Some Selected Culture- Associated Factors for their Effect on EPS Amount

\begin{tabular}{|l|l|l|}
\hline Factors & Variables & Concentration $\mathbf{( g ) / 1 0 0 m l}$ \\
\hline Carbon source & $\begin{array}{l}\text { Glucose, xylose, fructose, sucrose, } \\
\text { lactose }\end{array}$ & 3 \\
\hline Inorganic nitrogen source & $\mathrm{NH}_{4} \mathrm{Cl}, \mathrm{NH}_{4} \mathrm{SO}_{4}$ & 0.1 \\
\hline Organic nitrogen source & $\begin{array}{l}\text { Peptone, Beef extract, Yeast } \\
\text { extract }\end{array}$ & 0.05 \\
\hline $\begin{array}{l}\text { Phosphate salts } \\
\text { concentration }\end{array}$ & $\mathrm{K}_{2} \mathrm{HPO}_{4}$ & $0.07,0.14,0.28,0.56,1.12$ \\
\cline { 2 - 3 } & $\mathrm{KH}_{2} \mathrm{PO}_{4}$ & $0.03,0.06,0.12,0.24,0.48$ \\
\hline pH value & $5,6,7,8,9$ & \\
\hline
\end{tabular}

\section{Assessment of the effect of bacteria- associated factors on the amount of yield EPS}

1. The inoculums size: The basal medium was inoculated with graduated bacterial inocula (1 to $6 \% \mathrm{v} / \mathrm{v}$ ) and incubated under standard conditions to estimate the concentration of EPS produced by each inoculums volume (Wang et al., 2011).

2. The bacterial growth phase: The yield EPS in basal medium with maximal culture conditions was estimated over consequent incubation periods starting after 24 - 144h. (Czaczyk and Myszka, 2007).

\section{The amount of the yield EPS in basal medium}

\section{RESULTS AND DISCUSSION}

Based on the data listed in Table (2), the current study demonstrated that BSS was the most suitable medium that gave the larger amounts of EPS produced by the local isolate of $B$. subtilis. The weights of EPS, protein and carbohydrate concentrations obtained using BSS medium were greater than that of NFM and CDM. BSS was the excellent for production although the two other media were fitting to meet the high yield of EPS. BSS contains a nitrogen sources greater than CDM while NFM does not; also contains a greater concentration of carbon sources $(3 \%)$ than the two other media. The percentages of carbon and nitrogen sources play the most important role in cell growth and production of exopolymer. Also, BSS contains $3.5 \% \mathrm{NaCl}$ which enhanced larger amount of EPS up to $0.7 \%$ as it increases the osmotic pressure leading to detrimental effects on the cell (Abdul Razack et al., 2013). 
Table 2: The evaluation of EPS produced in basal medium

\begin{tabular}{|c|c|c|c|c|}
\hline \multirow{2}{*}{ Basal medium } & \multicolumn{4}{|c|}{ Estimations of EPS } \\
\cline { 2 - 5 } & $\begin{array}{c}\text { Wet weight } \\
(\mathbf{m g} / \mathbf{m l})\end{array}$ & $\begin{array}{c}\text { Dry weight } \\
(\mathbf{m g} / \mathbf{m l})\end{array}$ & $\begin{array}{c}\text { Carbohydrate } \\
(\mathbf{\mu g} / \mathbf{m l})\end{array}$ & $\begin{array}{c}\text { Protein } \\
(\boldsymbol{\mu g} / \mathbf{m l})\end{array}$ \\
\hline $\begin{array}{c}\text { Basal salt solution } \\
\text { ( BSS) }\end{array}$ & 15.0 & 0.986 & 390 & 79 \\
\hline Nitrogen free medium (NFM) & 12.8 & 0.958 & 320 & 84 \\
\hline $\begin{array}{c}\text { Chemically defined medium } \\
\text { (CDM) }\end{array}$ & 13.3 & 0.630 & 320 & 87 \\
\hline
\end{tabular}

Other comparison between the production media showed that B. subtilis MTCC121 isolate produced higher amount of EPS in basal medium than the other tested media (Vijayabaskar et al., 2011), while the isolate B. subtilis NCIM 2063 of (Borgio et al., 2009) produce higher concentration of EPS in NFM rather than BSS, Minimum salts medium, Milk medium, CDM, sewage water sample. FTIR spectrophotometer of the EPS showed the presence of carbohydrates bands, sugar derivatives, amino groups in the structure of EPS. For the EPS extracted from BSS, the sharp peak of alcoholic O-H was at $3400 \mathrm{~cm}^{-1}, \mathrm{~N}-\mathrm{H}$ or alcoholic O-H interfere with N-H (amines or amides) at $3327 \mathrm{~cm}^{-1}$, the presence of aliphatic C-H was detected at the stretching bands 2935- 2960 $\mathrm{cm}^{-1}$, of $\mathrm{C}=\mathrm{O}$ at the peak $1655 \mathrm{~cm}^{-1}$ (Fig.1). In the EPS extracted from NFM, the carboxylic O-H peak was at $3408 \mathrm{~cm}^{-1}$, N-H or alcoholic O-H interfere with $\mathrm{N}-\mathrm{H}$ (amines or amides) at $3325 \mathrm{~cm}^{-1}$, aliphatic $\mathrm{C}-\mathrm{H}$ at $2927 \mathrm{~cm}^{-1}$, the peak of $1653 \mathrm{~cm}^{-1}$ refers to $\mathrm{C}=\mathrm{O}$ band and at 1739 may indicate the presence of ester bond (Fig. 2). To the EPS extracted from CDM, the peak at $3483 \mathrm{~cm}^{-1}$ indicates the carboxylic $\mathrm{O}-\mathrm{H}$ and at $3290 \mathrm{~cm}^{-1}$ referrs to the N-H or (amines or amides), the presence of aliphatic C-H was detected at the stretching bands $2927-2980 \mathrm{~cm}^{-1}$, the $\mathrm{C}=\mathrm{O}$ band was at the peak $1647 \mathrm{~cm}^{-1}$. The other peaks refer to the presence of sugar derivatives, alcohols, ethers, esters, and phenols groups. (Fig.3)

In general, bacterial EPS polymers are mainly composed of carbohydrates with glucose, galactose and mannose monomers. Neutral sugars, some uronic acids and aminosugars are also frequently present. They may contain several organic esters- linked substitutes and pyruvate ketals. The presence of some acyl groups confers the EPS an anionic character, increases its lipophilicity and affects its capacity to interact with other polysaccharides (Frietas et al., 2011).

The main EPS component of B. subtilis isolated from Asian Sea Bass by Orosd and other (2012) was $50 \%$ carbohydrate, $26 \%$ protein and $24 \%$ fatty acid; the functional groups presented were $\mathrm{N}-\mathrm{H}$, alkenes, ketons, in addition to peak bands of alcohols, ethers, esters carboxylic acids, phenols groups. The presence of peak bands of these functional groups revealed the presence of many protein- related amine and amide groups indicating the possible presence of bacterial toxin, which deduce that EPS may contribute in pathogenesis; also, the presence of some phenolic and carboxylic groups may account for antibacterial activity. The chemical EPS composition of the fouling marine B. cereus GU812900 strain was $540.124 \mu \mathrm{g} / \mathrm{ml}$ sugar and $18.521 \mu \mathrm{g} / \mathrm{ml}$ protein (Bragadeeswaran et al., 2011). 


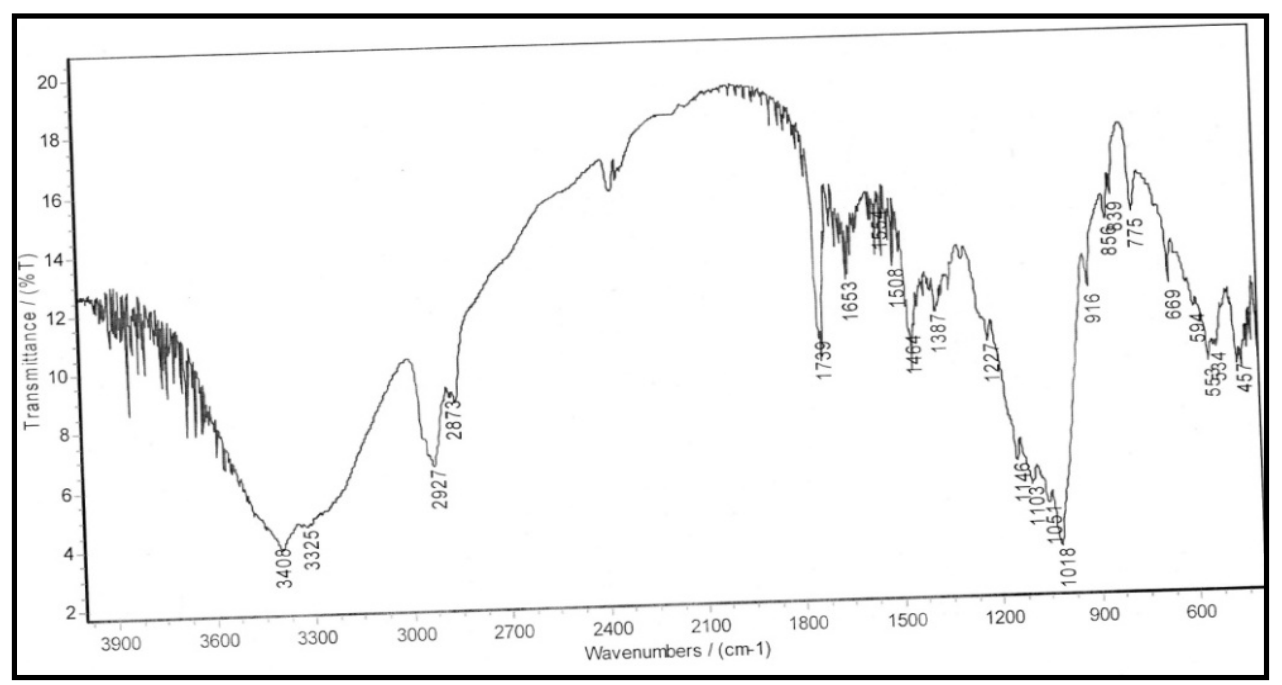

Fig. 1: FTIR spectra of the EPS by using BSS medium

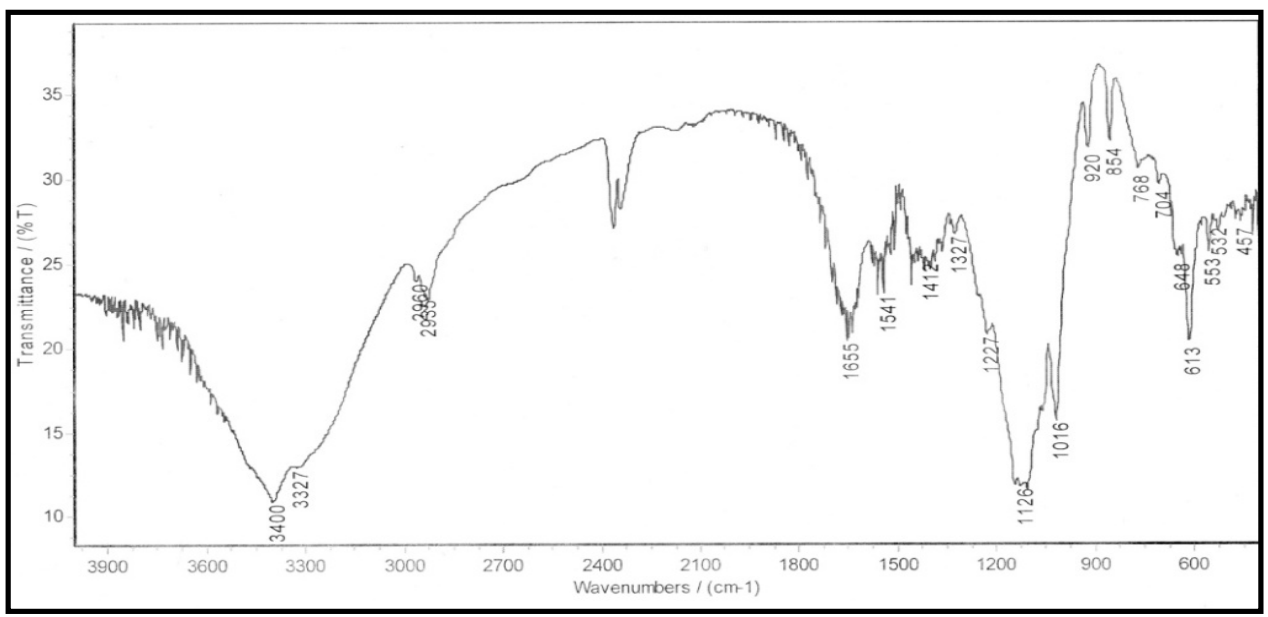

Fig. 2: FTIR spectra of the EPS by using NFM medium

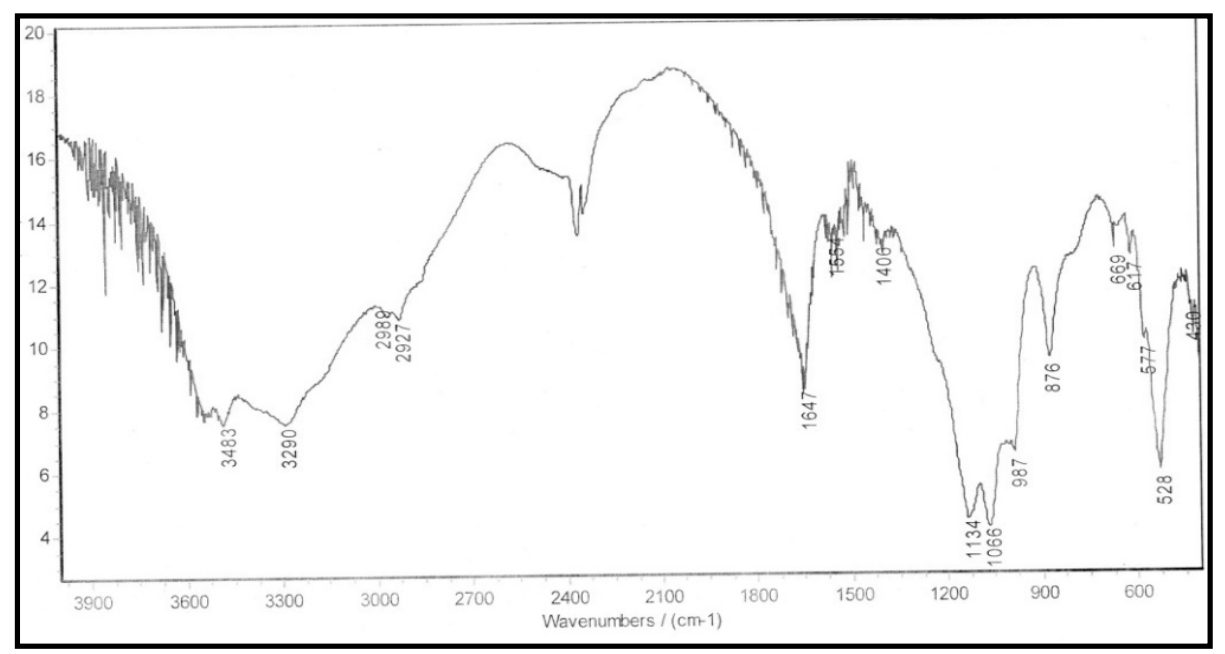

Fig. 3: FTIR spectra of the EPS by using CDM medium 


\section{The effect of culture medium- associated factors on the EPS yields}

The extracellular biopolymer 's synthesis by microbial cells depended on the carbon and nitrogen availability in the culture medium, most exopolymer producing microorganisms utilize carbohydrates as their carbon and energy source, sugars are the most commonly used carbon source for the production of bacterial EPS, (Czaczyk and Myszka, 2007; Frietas et al., 2011). So, effects of various nutrient sources like carbon and nitrogen and phosphate were determined in this study to find out the optimal source for maximum EPS production by B. subtilis, the concentrations used as their concentrations in basal medium BSS.

According to the results in Fig. 4, all the tested carbon sources were suitable to produce the EPS by $B$. subtilis under study; the most encouraging one was glucose and fructose as they cause the higher concentration of the yield EPS $(2950 \mu \mathrm{g} / \mathrm{ml})$ while lactose led to the lowest yield $(2430 \mu \mathrm{g} / \mathrm{ml})$. The inorganic nitrogen form, $\mathrm{NH}_{4} \mathrm{Cl}$ was the best in inducing the production $(3750 \mu \mathrm{g} / \mathrm{ml})$ than $\mathrm{NH}_{4} \mathrm{SO}_{4}$. The organic form of nitrogen, peptone was the best $(3690 \mu \mathrm{g} / \mathrm{ml})$ among the other tested forms, beef extract and yeast extract. The most favorable $\mathrm{pH}$ values of the medium that promote the greatest production were between 7.0- 8.0. (Fig. 4) also shows clearly that with the increasing phosphate salt concentrations the yield EPS will decrease obviously from 3690 to $1350 \mu \mathrm{g} / \mathrm{ml}$ with the increasing $\mathrm{K}_{2} \mathrm{HPO}_{4}$ concentration and from 3690 to $1340 \mu \mathrm{g} / \mathrm{ml}$ with increasing $\mathrm{KH}_{2} \mathrm{PO}_{4}$ concentrations. Medium and growth conditions are important factors for EPS production. The production and chemical characteristics of EPS are controlled by nutrient dynamics, microbial physiology, phytoplankton species, age of phytoplankton bloom, etc. It was cited that marine microbes grown in laboratory cultures will produce EPS when nutrients such as nitrogen, phosphorous, sulfur, and potassium are limited in the medium (Bragadeeswaran et al., 2011). Others cited that the presence of organic nitrogen is preferred if the bacterium is unable to build up particular essential amino acids and the organic nitrogen sources gave the higher amount of EPS than inorganic ones as the role of the heterotrophic B. subtilis in soil is decomposing and mineralizing the organic nitrogen present as a dissolved particle, this is one of the possible causes for EPS production by this bacterium; hence; when nitrogen source decreases, growth rate will ascend but EPS alleviation will occur (Abdul Razack et al., 2013).

Wang and his colleagues (2011) analyzed culture conditions for EPS production from $B$. thuringiensis 27 isolated from sand biological soil crusts; a sizeable change in EPS production was observed with different carbon sources; a high level of EPS obtained with maltose and glycerol as the carbon source with the maximum yield with 3\% maltose, the organic nitrogen was preferred than inorganic and peptone caused maximum production. Organic nitrogen sources are absorbed easier by the cell than the inorganic ones. The inorganic ions affect the EPS production via combining with enzymes. Also, $\mathrm{NaCl}$ was the most preferred among the tested mineral elements.

Other studies have shown that the EPS produced by GU812900 strain of the fouling marine $B$. cereus was affected by environmental conditions, especially availability of nitrogen which affected the carbohydrate and protein content of bacteria; in that nitrogen starvation may enhance carbohydrate production (Al-Nahas et al., 2011; Bragadeeswaran et al., 2011). Carbon sources are also of particular important, in that sucrose enhanced the elevated EPS concentration along with increasing sucrose elevation; among the tested nitrogen sources, ammonium sulfate produced the highest quantities of EPS; production was also continuously increased from 227.08 to $498.04 \mathrm{mg} / \mathrm{L}$ with gradual elevated phosphate concentration from 0.25 to $2 \mu \mathrm{g} / \mathrm{ml}$. (Bragadeeswaran et al., 2011). 


\section{Carbon source (3g\%)}

- Glucose

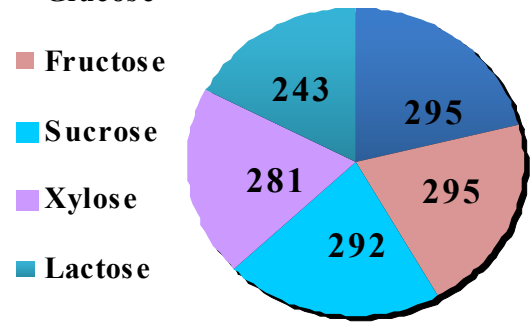

Inorganic nitrogen source

(0.1\%)

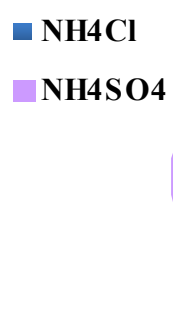

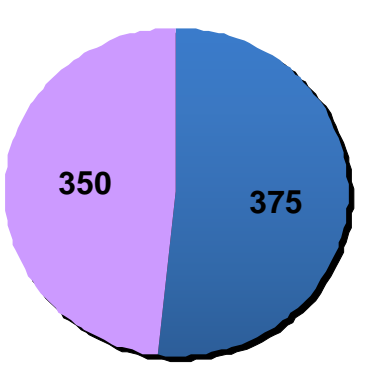

Organic nitrogen

source $(0.05 \%)$

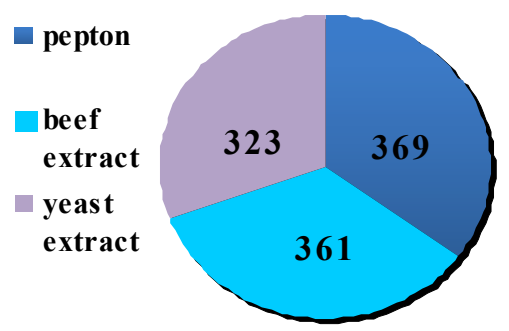

pH value

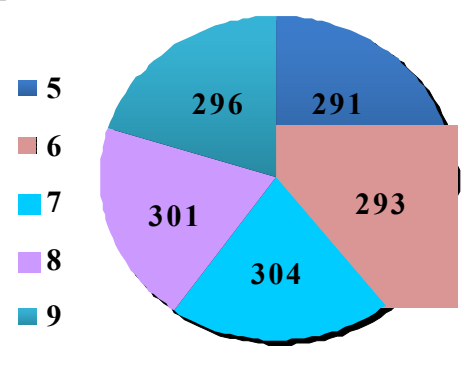

$\mathbf{K}_{2} \mathrm{HPO}_{4}(\mathrm{~g} \%)$

$\square .0^{-}$

$\square 0.14$

$\square 0.28$

0.56

$\square .12$

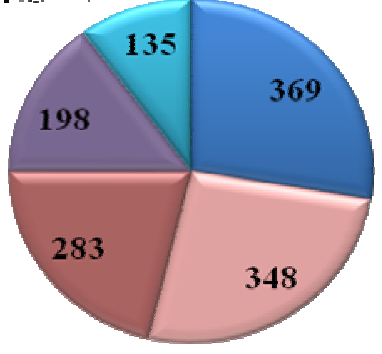

$\mathrm{KH}_{2} \mathrm{PO}_{4}(\mathrm{~g} \%)$

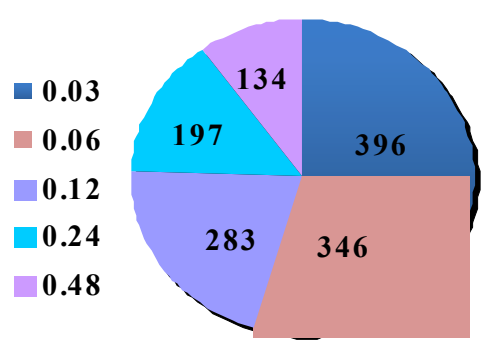

Fig. 4: Pie chart illustrates the effect of culture- associated factors that affect the amount of EPS pointed in concentration $\times 10 \mu \mathrm{g} / \mathrm{ml}$.

Other researchers showed that the EPS production by Bacillus subtilis was generally favored by high carbon and low nitrogen ratio in the medium (Borgio et al., 2009). The $\mathrm{pH}$ value of the medium is another critical factor that affects the production of EPS; the preferred $\mathrm{pH}$ values of the Bacillus isolate under study was between 7.0-8.0; dissident this range causes lowered amounts of produced EPS. This was fitted to $\mathrm{pH}$ values recorded to other Bacillus isolates as the production occurred at 5.0-9.0 $\mathrm{pH}$ range with the maximum at 7.0 (Wang et al., 2011).

\section{Bacteria- associated factors that affect the amount of EPS}

The bacterial inoculum volume:

The correlation between the resulted EPS with the bacterial cell concentration is plained in (Fig. 5). The results indicated that 5\% and 6\% inoculums size gave the maximum EPS yield 2950 $\mu \mathrm{g} / \mathrm{ml}$ and $3010 \mu \mathrm{g} / \mathrm{ml}$ respectively. With the increased bacterial lawn, the amount of EPS will increase, that means the increase of bacterial cell that construct the EPS substance in a given period. 


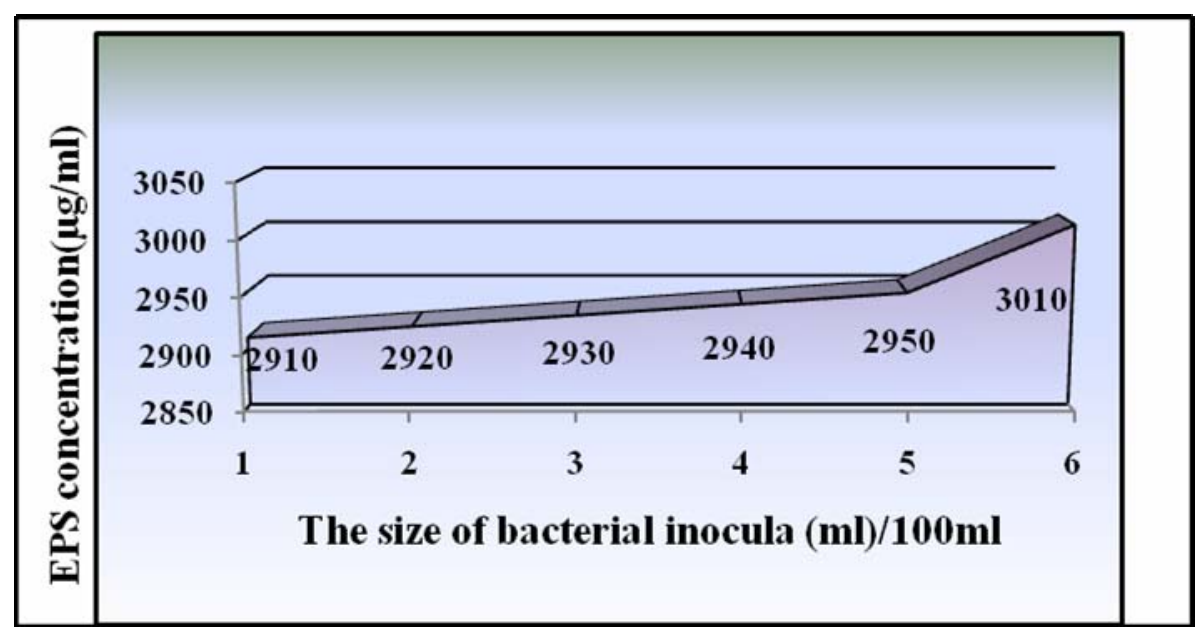

Fig. 5: The effect of different bacterial inoculums size on the amount of the yield EPS

Among several bacteria physiological properties, inoculum size may play an important role in cell reproduction and EPS production; it was recorded that $8 \%$ inoculum size in $25 \mathrm{ml}$ of medium was best for EPS production (Chen et al., 2008). The same conclusion was observed with $B$. thuringiensis 27 where Wang and his colleagues (2011) recorded that inoculum size of 8\% was fit for maximal EPS production.

\section{Relationship of the amount of produced EPS with the incubation periods:}

The concentration of produced EPS over 7 days of incubation is pointed up in (Fig. 6). The concentration of EPS increased along with extension of incubation period to reach its max level after 4 days of incubation $3230 \mu \mathrm{g} / \mathrm{ml}$, beyond that the yield gradually decreased to reached 2190 $\mu \mathrm{g} / \mathrm{ml}$ after 7 days. Along with incubation period, the bacteria will utilize carbon and nitrogen sources leading to increasing cell number; after deletion the existing sources, it will be subjected to scarcity of nutrients which stimulate the production of EPS as a response to starvation conditions; this was noted after 4 days of incubation. After that the amount of EPS was observed to lower as the bacteria began to consume the EPS component during starvation conditions.

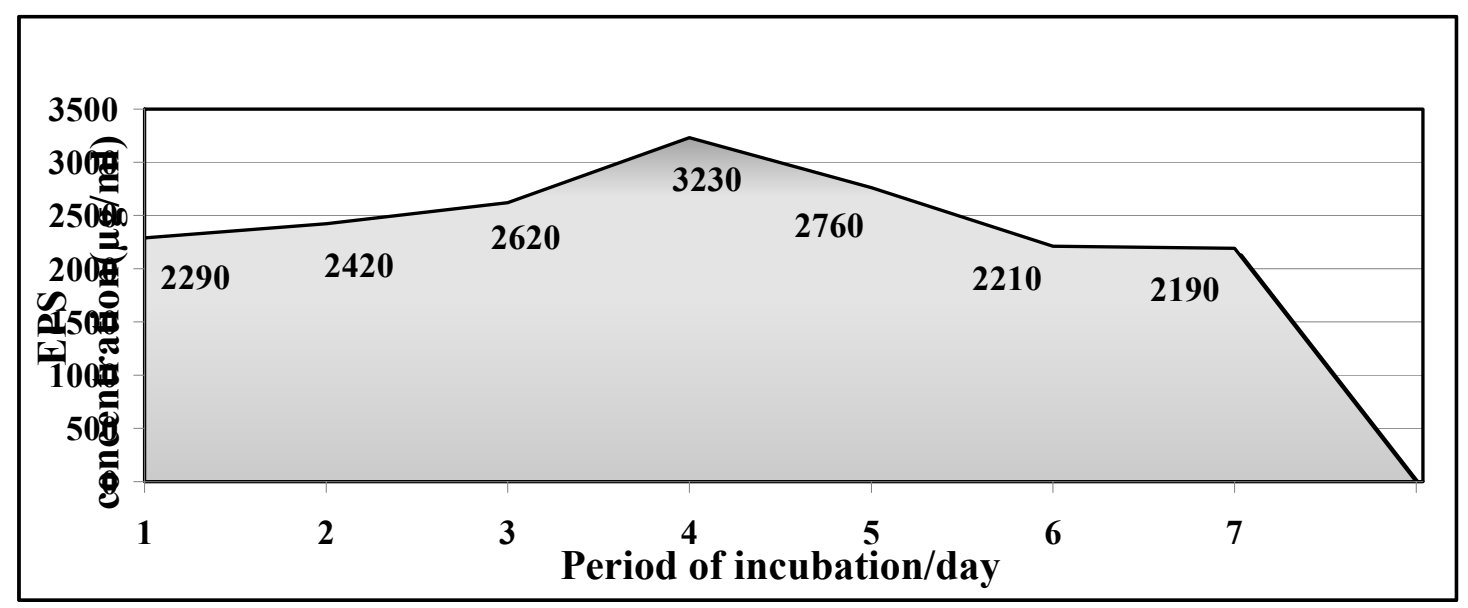

Fig. 6: The amount of EPS produced at different incubation periods 
Maturation of the pellicle formed by B. subtilis occur after three days of incubation, after that disassembling and releasing individual planktonic cells will occur after 8 days of incubation (Kolodkin-Gal et al., 2012). It was reported that after few days the onset of EPS production from bacteria, its level in the culture medium declined which might be due to the secretion of $\beta 1,3$ glucanases (Vijayabaskar et al., 2011). Other observation on EPS in aqueous phase from $B$. subtilis showed that the composition of the functional groups of the matrix depends on the cell growth phase (e.g. exponential vs. stationary) (Omoike and Chorover, 2004). The EPS produced by GU812900 strain of the fouling marine B. cereus was observed at all stages of culture growth and was higher during the stationary phase. The release of EPS by bacteria is generally low during exponential growth and it accumulate during the stationary phase (Bragadeeswaran et al., 2011).

\section{CONCLUSION}

Medium conditions are important factors for EPS production and the maximum yield of EPS produced is known to be influenced by the composition of the nutrients in the media in which the bacterium is grown. When compared the three culture media used in the study, basal salt solution (BSS), nitrogen- free medium (NFM) and chemically defined medium (CDM) for their ability to induce the primary EPS production, it was concluded that EPS extract was higher in BSS basal medium than the other in which the dry weight was $0.986 \mathrm{mg} / \mathrm{ml}$. From a FTIR analysis to EPS produced display presence of different functional groups such $\mathrm{OH}, \mathrm{C}=\mathrm{O}, \mathrm{COOH}$. Various factors influencing EPS production such as $\mathrm{pH}$, inoculums size, incubation periods, carbon, nitrogen and phosphate source.

\section{REFERENCES}

Abdul Razack, S.; Velayntham, V.; Thangavelu, V. (2013). Medium optimization for the production of exopolysaccharide by Bacillus subtilis using synthetic sources and agro wastes. Turk. J. Biol., 37, 1-7.

Al-Nahas, M.O.; Darwish, M.M.; Ali, A.E. (2011). Characterization of an exopolysaccharideproducing marine bacterium, isolate Pseudoalteromonas sp. A.M. Afr. J. Microbiol. Res. 5, 3823-3831.

Bais, H.; Fall, R.; Vivanco, J. (2004). Biocontrol of Bacillus subtilis against infection of Arabidopsis roots by Pseudomonas syringae is facilitated by biofilm formation and surfactant production. Plant physiolo., 134, 307-319.

Borgio, J.; Bency, B.; Ramesh, S.; Amuthan, M. (2009). Exopolysaccharide production by Bacillus subtilis NCIM 2063, Pseudomonas aeruginosa NCIM 2862 and Streptococcus mutans MTCC 1943 using batch culture in different media. Afr. J. Biotechnol., 9 (20), 5454-5457.

Bragadeeswaran, S.; Jeevapriya, R.; Prabhu, K.; Rani, S.; Priyadharsini, S.; Balasubramanian, T. (2011). Exopolysaccharide production by Bacillus cereus GU812900, a fouling marine bacterium. Afr. J. Microbiol. Res., 5 (24), 4124-4132.

Chen, W.; Zhao, Z.; Chen, S.; Li, Y. (2008). Optimization for the production of exopolysaccharide from fomes fomentarius in submerged culture and its antitumor effect in vitro. Bioresour. Technol., 99, 3187-3194.

Czaczyk, K.; Myszka, K. (2007). Biosynthesis of extracellular polymeric substances (EPS) and its role in microbial biofilm formation. Polish. J. of Environ. Stud., 16(6), 799-806.

Dubois, M.; Gilles, K.A.; Hamilton, J.K.; Rebers, P.A.; Smith, F. (1956). Colorimetric method for determination of sugars and related substances. Anal. Chem., 28, 350-356.

Earl, A.; Losick, R.; Kolter, R. (2008). Ecology and genomics of Bacillus subtilis. Trends Microbiol., 16, 269-275.

Freitas, F.; Alves, V.; Reis, M. (2011). Advances in bacterial exopolysaccharide: from production to biotechnological application. Trends Biotechnol., 29(8), 388-398. 
Kolodkin-Gal, I.; Cao, S.; Chain, L.; Böttcher, T.; Kolter, R. ; Clardy, J. (2012). A self- produced trigger for biofilm disassembly that targets exopolysaccharide. Cell, 149, 684-692.

Lemon, K.P.; Earl, A.M.; Vlamakis, H.C.; Aguilar, C.; Kolter, R. (2008). Biofilm development with an emphasis on Bacillus subtilis. Curr. Top. microbial. Immunol., 322, 1-16.

Lowry, O.H.; Rosebrough, N.J.; Farr, A.L.; Randall, R.J. (1951). Protein measurement with the Folin phenol reagent. J. Biol. Chem., 193, 265-275.

Marvasi, M.; Visscher, P.; Martinez, L. (2010). Exopolymeric substances (EPS) from Bacillus subtilis: polymers and genes encoding their synthesis. FEMS Microbiol. Lett., 313, 1-9.

Nadell, C.; Xavier, K.; Foster, K.(2009). The sociobiology of biofilms. FEMS Microbiol Rev.,33, 206-224.

Ohno, N.; Miura, N.; Nakajima, M.; Yadomae, T. (2000). Antitumor 1-3-ß-glucan from cultured fruit body of Sparasis crispa. Boil. Pharm. Bul., 23, 866-872.

Omoike, A.; Chorover, J.( 2004). Spectroscopic study of extracellular polymeric substances from Bacillus subtilis: aqueous chemistry and adsorption effects. Biomacromole. J., 5, 12191230.

Orsod, M.; Joseph, M.; Huyop, F.(2012). Characterization of exoplolysaccharide produced by bacillus subtilis and Brachybacterium sp. isolated from Asian Sea Bass (Lates calcarifer). Mal. J. Microbial., 8 (3), 170-174.

Penge, G.; Hongjie, G.; Wen, Y.; Song, K.(2008). Current understanding on biosynthesis of microbial polysaccharides. Curr. Topics Med. Chem., 8 (2),141-151.

Rubinstein, S.; Kolodkin-Gal, L.; Mcloon, A.; Chai, L.; Kolter, R.; Losick, R.; Weitz, D.(2012). Osmotic pressure can regulate matrix gene expression in Bacillus subtilis. mol. Microbiol., 86 (2), $462-471$.

Türetgen, İ.; Şanlı, N.; Norden, I.(2012). Biofilm formation comparison of the SANIPACKING cooling tower fill material against standard polypropylene fill material in a recirculating model water system. Turk. J. Biol., 36, 313-318.

Vidhyalakshmi, R.; Nachiyar, C. (2011). Microbial production of exopolysaccharides. J. Pharmacol. Res., 4, 2390-2391.

Vijayabaskar, P.; Babinastarlin, S.; Shankar, T.; Sivakumar, T.; Anandapandian, K.(2011). Quantification and characterization of exopolysaccharides from Bacillus subtilis (MTCC 121). Advan. Biol. Res., 5 (20), 71-76.

Wang, Z.; Sheng, J.; Tian, X.; Wu, T.; Liu, W.; Shen, L.(2011). Optimization of the production of exopolysaccharide by Bacillus thuringiensis 27 in sand biological soil crusts and its bioflocculant activity. Afr. J. Microbiol. Rse., 5 (16), 2359-2366. 